\title{
Could We Derive Benefit from Implementing Electronic Medical Records in Hospital? A Structured Evidence and Narrative Review
}

\section{Mampukan Kita Mendapatkan Manfaat dari Penerapan Rekam Medis Elektronik Di Rumah Sakit? Sebuah Ulasan Naratif dan Bukti Terstruktur}

\author{
Sarah Rosiana Rahmawati and Mardiati Nadjib \\ Faculty of Public Health, Universitas Indonesia, Depok, West Java, Indonesia
}

\begin{abstract}
Corresopnding author: Sarah Rosiana Rahmawati, Faculty of Public Health, Universitas Indonesia, Depok, West Java, Indonesia, E-mail: sarahrosianarahmawati@gmail.com
\end{abstract}

\begin{abstract}
One method chosen by many hospitals to achieve efficiency is the use of an Electronic Medical Record (EMR) system. This study discusses the EMR and its relationship with the efficiency and quality of hospital services through patient outcomes and users' (physicians' and nurses') perspectives. A structured evidence and narrative review using the PRISMA method, with articles retrieved from online databases including PubMed, Wiley, ScienceDirect and ProQuest. The study's period of review dates back ten years. The advantages of EMRs are decreased length of stay (LOS) and infection rate, plus a reduced probability of readmission once a patient safety event has occurred. EMRs reduce nurse, licensed vocational nurse (LVN) and registry cost per hour. EMRs provide enhanced ability in completing medical records and clinical documentation. The disadvantages are greater inefficiency in medical-surgical acute settings and increased cost per patient day. EMR does not reduce LOS in ICU. Some physicians also complain about the inefficiencies and time loss created by EMR. The implementation of EMR in hospitals has advantages and disadvantages. Hospital management should undertake more analysis and consideration prior to deciding whether or not to use EMR.
\end{abstract}

Keywords: Electronic medical records, hospital, patients' outcomes, efficiency

\section{ABSTRAK}

Salah satu metode dipilih oleh banyak rumah sakit untuk mencapai efisiensi adalah penggunaan sistem rekam medis elektronik (RME). Studi ini mengemukakan RME dan hubungannya dengan efisiensi dan kualitas pelayanan rumah sakit melalui hasil pasien dan persepsi pengguna (dokter dan perawat). Sebuah ulasan naratif dan bukti terstruktur menggunakan metode PRISMA, dengan artikel diperoleh dari basis data daring terdiri dari PubMed, Wiley, ScienceDirect dan ProQuest. Periode studi yang digunakan adalah sepuluh tahun ke belakang. Keuntungan dari RME adalah menurunkan lama rawat inap (LOS) dan tingkat infeksi, dan mengurangi probabilitas readmisi ketika risiko keselamatan pasien terjadi. RME menurunkan biaya perawat, dengan hanya mempekerjakan perawat vokasi berlisensi (LVN) dalam melakukan registrasi pasien tiap jamnya. RME mampu menyediakan kesempatan untuk menuntaskan data rekam medis dan dokumentasi klinis pasien. Kerugiannnya adalah inefisiensi yang lebih besar di dalam pelayanan bedah akut dan meningkatkan biaya per hari pasien. RME tidak menurunkan LOS di ICU. Beberapa dokter juga mengajukan keberatan dengan inefisiensi dan hilangnya waktu yang diakibatkan oleh RME. Penerapan RME di rumah sakit memiliki untung-rugi. Manajemen rumah sakit harus lebih teliti menganalisis dan menimbang sebelum memutuskan apakah memakai RME atau tidak.

Kata kunci: rekam medis elektronik, rumah sakit, hasil pasien, efisiensi 


\section{INTRODUCTION}

Health is a state of complete physical, mental and social well-being and not merely the absence of disease or infirmity (WHO, 2018). In 1986, WHO stated in the Ottawa Charter for Health Promotion that health is a human right. In order to achieve this right, many countries around the world have a system of universal health coverage for their populations. Such systems cover both primary care and hospital care. A consequence of the implementation of this type of system is that many hospitals must face the 'reality' that the price of services is set by the government. Hospital management must find a way to use 'the given price' as efficiently as possible in order to avoid a loss.

A hospital is a health service institution for society with its own characteristics that are influenced by the development of health science, technological progress and the socioeconomic life of the society. It must be capable of delivering ever greater improvements to service and be accessible by the society it serves in order to realise the highest degree of health. Hospitals thus provide medical services to the community. In particular, some hospitals provide different levels of care in terms of the technical sophistication and quality of services they provide or the seriousness and complexity of the illnesses they treat (Santerre \& Neun, 2010).

Medical services constitute the final output of the medical services industry and that given this output, it is important to determine the level of efficiency with which the services are produced (Feldstein, 1983). Meanwhile, efficiency is the one of the 10 (ten) important keys in the concept of economic efficiency, which is a measure of how well resources are being used to promote social welfare. Inefficient outcomes waste resources, while the efficient use of scarce resources enhances social welfare (Henderson, 2002).

One method that many hospitals have chosen in order to achieve efficiency is the use of an Electronic Medical Record (EMR) system. They believe that the implementation of an EMR system can generate efficiencies since there is paperless recording of patient data, which in turn will reduce the costs of production. In addition to reducing costs, they also believe that
EMR implementation has the potential to make services faster, reduce the reliance on illegible handwriting, which in turn improves patient safety, and increase patient satisfaction.

Electronic Medical Records (EMR) is a computerized health information system which contains demography data, medical data and could be equipped with a decision support system' (Andriani et al., 2017). Health care providers implement EMR to improve quality of services, improve patient satisfaction, enhance the accuracy of documentation, reduce clinical errors and accelerate the accessibility of patient data (Bilimoria, 2007).

EMR systems have the potential to improve care quality and efficiency (Xue et al., 2012). Of present interest, systems of EMR and computerized provider order entry (CPOE) are two promising forms of health information technology (IT), whose success has been stalled in part from a beliefs elicitation study of health IT focusing on physicians' use of EMR and CPOE for inpatient and outpatient care (Asyary et al., 2013, Holden, 2010). EMRs are in widespread use around the world. This review contributes more information about EMR and its relationship with the efficiency and quality of hospital services through patient outcomes.

\section{SUBJECTS AND METHODS}

The subject of this study is EMRs. The study employed a structured evidence and narrative synthesis with PRISMA method to retrieve articles from online databases such as PubMed, Wiley, ScienceDirect, JStor and ProQuest, using the keywords 'hospital' AND 'efficiency' OR 'cost efficiency' AND ‘quality' OR 'patient's outcomes'. The study had a review period of ten years (2008-2018).

A total of 30 documents were returned by a search of the ScienceDirect search engine using the keywords 'hospital' AND 'electronic medical records' AND 'efficiency' AND 'quality' for the review article and research article categories. Fourteen documents were selected based on a title review; of these, two documents were selected based on a full-text review and assessed for eligibility.

Eight documents were returned by the PubMed search engine, using the keywords 
'hospital (title/abstract)' AND ‘electronic medical records (title/abstract)' AND 'efficiency (title/ abstract)' AND 'quality (title/abstract)' AND 'outcomes (title/abstract)'. A title review led to the selection of six documents, three of which were selected following a full-text review and assessed for eligibility. The Wiley search engine returned five documents from a search using the keywords 'hospital (title)' AND ‘electronic medical records (title)'. Of these, three documents could not be accessed, thus resulting in two documents. All of the documents were selected based on a full-text review and assessed for eligibility. The ProQuest search engine returned a total of 9,022 documents based on a search using the keywords 'hospital (all fields)' AND 'efficiency (all fields)' AND 'quality (all fields)' AND 'electronic medical records (all fields)' for the period 2008-2018.

We subsequently amended 'hospital (all fields)' AND 'efficiency (all fields)' AND 'quality (all fields)' AND 'electronic medical records (all fields)' to more abstract criteria, which resulted in 31 documents. A review of the titles led to 15 documents being selected, four of which were chosen following a full-text review and assessed for eligibility. Two articles matching the aim of this study were retrieved from the local journal Portal Garuda. One of these was selected following a full-text review and assessed for eligibility.

Those articles that were included and assessed as being eligible in this review were those that demonstrated an effect of using EMRs. Such effects included reduced length of stay (LOS), a decrease in mortality rate, reduced infection rate and increased user satisfaction. We included the period 2008-2018 and adult patients (19-65+ years old). The articles excluded from this review did not contain any results based on EMR, featured patients under 19 years old and/or were for years prior to 2008 .

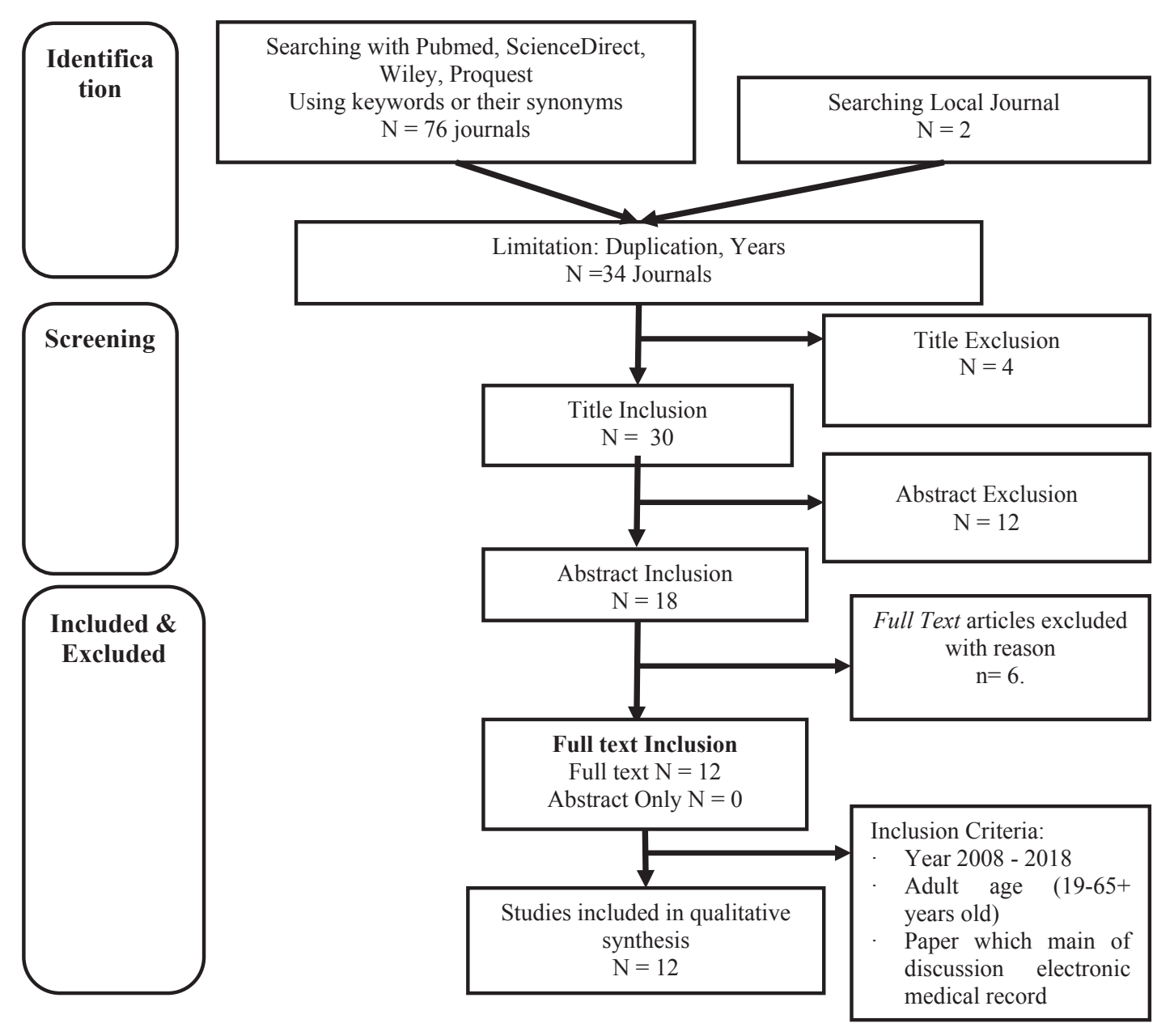

Figure 1. Inclusion and Exclusion Criteria 


\section{RESULTS}

A study conducted in China found that length of stay (LOS) grew at a rate of 0.027 beddays per month in the pre-EMR period (January 2005-December 2006) ( $\mathrm{SD}=0.011, \mathrm{p}=0.02)$, before subsequently falling by 0.043 bed-days per month in the post-EMR period $(\mathrm{p}<0.001)$. From January 2007, when EMR was being used by all physicians, LOS rose by 0.295 bed-days, although this was not significantly higher than expected when compared to the trend prior to the go-live month $(\mathrm{p}=0.13)$. Infection rate rose by 0.036 infections per 100 patients per month for the period from before the EMR go-live month in January 2005 to December 2006 (p < 0.01 ), before falling by 0.062 infections per 100 patients per month in the post-EMR period. In January 2007, the infection rate rose by 0.244 bed-days, but this increase was not significant ( $\mathrm{p}$ $=0.13$ ). There was an increase in the mortality rate prior to the EMR go-live month, with the rate of increase standing at 0.048 deaths per 100 patients for the period January 2005-December 2006 ( $p=0.001)$. After the EMR go-live month, the mortality rate fell by 1.039 deaths per 1000 patients $(p<0.001)$, decreasing at a rate of 0.005 deaths per 1000 patients per month in the postEMR period $(p=0.001)$. The cost per patient stay fell by 33 Renminbi (RMB) per month in the preEMR period $(p=0.002)$ and increased at the rate of $16 \mathrm{RMB}$ per month in the post-EMR period ( $\mathrm{p}$ $<0.001$ ) (Xue et al., 2012).

A 2010 study conducted in California, USA used panel data on Californian hospitals for the period 1998-2007. The study employed Stochastic Frontier Analysis (SFA) to estimate the relationship between EMR implementation and the cost inefficiency of medical-surgical units and categorised EMR into the following three stages (Furukawa, Raghu, \& Shao, 2010):

- Stage 1: EMR in all three ancillary systems (laboratory, radiology, pharmacy) and a clinical data repository (CDR). The CDR system receives feeds from the ancillary systems and provides clinical workers with access to patient information.

- Stage 2: EMR implemented in nursing documentation (DOC) and electronic medication administration records (eMAR), in addition to attaining EMR Stage 1. DOC enables the creation of nursing care plans for patients, with these plans then used to standardise and document the treatments provided. eMAR serves to automate medication administration at the point of care, provides nurses with access to patient medication data and reconciles the medication administration with physician ordering and pharmacy dispensing.

- $\quad$ Stage 3: in addition to attaining EMR Stages 1 and 2, there has been investment in clinical decision support (CDS) and CPOE. EMR Stage 3 functionality is characterised by the automation of clinical decision processes, including order entry management and support for clinical decision-making.

Contrary to their expectation, EMR, especially in Stages 1 and 2, registered higher inefficiency in medical-surgical acute settings (Furukawa et al., 2010). In conclusion, the study found that most of the inefficiencies were associated with the implementation of nursing documentation, electronic medication administration reports and CDS (Furukawa et al., 2010).

The implementation of EMR to yield positive impacts for quality improvement. These impacts comprised a median of EMR of 12 minutes compared to a median for paper-based medical records of 10 minutes; however, EMR achieved a rate of 85.71 per cent completeness in the filling in of medical records, versus 75 per cent for paper-based medical records (Erawantini, Nugroho, Sanjaya, \& Hariyanto, 2012). Clinical documentation in EMR was also found to be better than for paper-based medical records, standing at 67.84 per cent for EMR and 66.84 per cent for paper-based medical records, while the users also reported that they felt satisfied with the contents, accuracy and format of EMR (Erawantini, Nugroho, Sanjaya, \& Hariyanto, 2012).

In another study on the implementation of EMR, it aimed to estimate the effects of EMR implementation on medical-surgical acute unit costs, LOS, nurse staffing levels, nursing skill mix, nurse cost per hour and nurse-sensitive patient outcomes (Furukawa et al., 2010). EMR Stage 2 (EMR-S2) and EMR Stage 3 (EMR-S3) 
were associated with $5.9-10.3$ per cent higher costs per discharge (Table 1). These increased costs were due to both higher cost per patient day and higher LOS. EMR-S3 resulted in an increase in cost per patient day of 5.0-9.6 per cent coupled with a 3.7-4.4 per cent increase in LOS. EMR-S1 was associated with a 2.1 per cent higher LOS in year 1 of implementation.

With respect to the effect of EMR implementation on nursing Hour Per Patient Day (HPPD), all three stages of EMR implementation led to an increase in nurse staffing levels. Total nursing hours increased by $13.3-14.6$ percent under EMR-S1, by 11.2-21.6 percent in EMR-S2 and by 16.0-19.4 percent during EMR-S3. The increase in total HPPD was due to higher staffing levels for Registered Nurses (RN) and aides. RN staffing increased by 14.3-15.4 percent for EMR-S1, 14.6-25.8 percent during EMR-S2 and 18.7-22.2 per cent for EMR-S3. Aide staffing increased by 20.0-21.0 percent under EMR-S1, 13.7-22.2 percent during EMR-S2 and 14.8-30.5 percent for EMR-S3 (Furukawa et al., 2010).

It found little evidence of the relationship between EMR implementation and nursing skill mix (Furukawa et al., 2010). EMR-S3 was associated with a 1.9-2.3 percent lower Registry percent during years 2-3 of implementation, while EMR-S1 and EMR-S2 were not associated with any significant changes in nursing skill mix (Furukawa et al., 2010). EMR implementation generally led to a decrease in nurse cost per hour; EMR-S1 resulted in a decrease in RN cost per hour of 1.8 per cent in year 2, a decrease in licensed vocational nurse (LVN) cost per hour of 3.2-4.5 per cent, a decrease in AID cost per hour of 1.7-2.6 per cent and a decrease in Registry cost per hour of 5.1 per cent in year 1 of implementation. EMR-S2 decreased LVN cost per hour by 2.1-4.3 per cent. EMR-S3 decreased LVN cost per hour by 3.7-4.5 per cent in years 1-2 and decreased Registry cost per hour by 8.4 per cent in year 1 of implementation (Furukawa et al., 2010).

Furukawa et al. (2010) found evidence that EMR implementation had a significant effect on nurse-sensitive patient outcomes. EMR-S1 was associated with a 1.4-1.7 per cent higher rate of complications in years 2-3 of implementation. However, their study found no relationship between EMR-S1 and rates of in-hospital mortality or specific complications. EMR-S2 had little impact on patient outcomes. The only significant effect was a 16.7-16.9 per cent lower rate of Acute Myocardial Infarction (AMI) mortality in years 2-3 of implementation. EMR-S3 was associated with higher rates of complications but lower rates of mortality. EMR-S3 increased complications by 2.3-3.0 per cent in years $2-3$ and decreased mortality for conditions by 3.0-4.2 per cent (Furukawa et al., 2010).

A study carried out in Australia in 2017 found that for EMR functions, there was moderatequality evidence of reduced hospitalisations and LOS, and low-quality evidence of improved organisational efficiency, greater accuracy of information and reduced documentation and process turnaround times (Keasberry, Scott, Sullivan, Staib, \& Ashby, 2017). In a high-quality review, there was moderate-quality evidence of a 15 per cent reduction in hospitalisations and small decreases in both the length of hospital stay and the number of patient visits to emergency departments as a result of electronically generated reports of investigations containing care recommendations (Keasberry et al., 2017). The same review noted no improvement in the timeliness of discharge summaries to primary care providers and no effects on disease-specific processes of care or clinical outcomes. Two reviews, one low quality and another high quality, that examined in-hospital mortality showed no effects from EMR (Keasberry et al., 2017).

A study in 2012 found that EMRs do not reduce the rate of patient safety events. However, once an event occurs, EMRs reduce death by 34 per cent, readmissions by 39 per cent and spending by $\$ 4,850(16 \%)$, a cost offset of $\$ 1.75$ per $\$ 1$ spent on IT capital. Thus, EMRs can help contain costs by better coordinating care to recover patients from medical errors once they occur (Encinosa \& Bae, 2012).

The hospitals employing EMRs showed no statistically significant difference in their rates of patient safety events compared to hospitals without EMRs (Encinosa \& Bae, 2012). Indeed, across all types of events, EMR hospitals did not differ in their mix of patient safety events compared to hospitals without EMRs. Moreover, 
it stated that spending per patient safety event seemed to be systematically lower in the EMR hospitals across all types of events (Encinosa $\&$ Bae, 2012). For all safety events, the average spending on a patient safety event was $\$ 55,810$ with EMRs, compared to $\$ 60,093$ without EMRs. However, for overall surgeries, event or no event, EMR surgeries were shown to be more expensive; the total 90-day spending for surgeries with EMRs was $\$ 29,967$ on average, versus $\$ 29,296$ for surgeries without EMR (Encinosa \& Bae, 2012). This study also mentioned that EMRs were found to have no statistically significant impact on death, while the occurrence of a patient safety event was a strong predictor of death (Encinosa $\&$ Bae, 2012). However, the coefficient for the EMR-patient safety event interaction was -.249 , statistically significant at the 95 per cent level. This indicates that EMRs reduce the probability of death once a patient safety event occurs. The excess death rate due to patient safety events in hospitals without basic EMRs is 2.6 per cent $(3.4 \%-0.8 \%)$, while the excess death rate due to patient safety events with basic EMRs is 1.7 per cent $(2.5 \%-0.8 \%)$. Thus, the excess death rate due to patient safety events is reduced by 34 per cent due to EMRs $\{(2.6-1.7) / 2.6\}$ (Encinosa \& Bae, 2012). EMRs had no statistically significant impact on readmissions. Whilst the occurrence of a patient safety event was a strong predictor of readmission, the coefficient for the EMR-patient safety event interaction was -.116 , statistically significant at the 90 per cent level. This indicates that EMRs reduce the probability of readmission once a patient safety event occurs (Encinosa \& Bae, 2012). This research pointed to an excess readmission rate due to patient safety events in hospitals without basic EMRs of 8.9 per cent (23.4\%-14.5\%), while the excess readmission rate due to patient safety events in hospitals with basic EMRs was 5.4 per cent (18.8\%-13.4\%); thus, the excess readmission rate due to patient safety events fell by 39 per cent due to EMRs $\{(8.9-5.4) / 8.9\}$ (Encinosa \& Bae, 2012).

This study went on to present Heckman estimates of the impact of EMRs on spending. The coefficient for a patient safety event is .70, while in hospitals without EMRs the coefficient for patient safety is much higher, at .76 (Encinosa $\&$ Bae, 2012). This indicates that EMRs result in a smaller impact on spending caused by patient safety events. The excess spending due to patient safety events in hospitals without basic EMRs was $\$ 31,297$ ( $\$ 57,583-\$ 26,286)$, while the excess spending due to patient safety events in hospitals with basic EMRs was \$26,448 (\$52,465$\$ 26,017)$. Thus, excess spending due to patient safety events declined by $\$ 4,849$, or 16 per cent, due to basic EMRs $\{(\$ 31,297-\$ 26,448) / \$ 31,2\}$ (Encinosa \& Bae, 2012).

Meanwhile, research was conducted in the Netherlands to observe and analyse the impact of EMR on LOS among colorectal cancer patients. The hypothesis was that in hospitals with more advanced EMR capabilities, there is an increased likelihood of a shorter average LOS for colorectal surgery patients, and this was supported by the study's findings. Another study divided the distribution of patients' characteristics into two groups - an Electronic Medical Record Adoption Model(EMRAM) low group and an EMRAM high group (van Poelgeest et al., 2017). A significant effect (relative median LOS $=0.774$, CI 95\%) was found between patients in the EMRAM low group and the LOS in the EMRAM high hospital group when corrected for case mix, year of operation and type of surgery (laparoscopy or laparotomy). Additional adjustment for patients with complication confirmed the association (relative median LOS $=0.969$, CI 95\%) (van Poelgeest et al., 2017).

This study stated that for LOS in ICU, multivariate regression did not reveal a significant association between higher EMRAM score and smaller LOS (relative median LOS $=0.995$, CI 95\%), and after adjustment for patients with complications there was also no significant association (relative median LOS $=1.010$, CI 95\%) (van Poelgeest et al., 2017). Their hypothesis suggesting an increase in the likelihood of a shorter average LOS for colorectal surgery patients in academic-affiliated hospitals with more advanced EMR capabilities was also not supported by the study's results, with these instead showing a significant negative association (relative median LOS $=0.934$, CI 95\%) (van Poelgeest et al., 2017).

In a study carried out in the USA, found the mean values to suggest that documentation issues, efficiency in patient processing and 
administrative issues were the top three areas that physicians expected to be impacted by EMR (Vishwanath et al., 2010). Documentation issues included issues such as the high volumes of documentation required to minimize liability and difficulty in performing accurate coding of clinical encounters, efficiency in patient processing included issues such as the overbooking of schedules and patients arriving without appointments, while administrative issues included aspects such as inadequate ancillary support and difficulty in changing how clinics operate (Vishwanath et al., 2010). Patient safety and care, economic challenges and reimbursement, and basic clinical processes were at the bottom of the issues expected to be impacted by EMR (Vishwanath et al., 2010).

It stated that, for instance, the significant beta value found for administration issues (0.45) indicated that as physicians' attitudes towards health IT increased by one standard deviation (1.0), their expectations regarding the impact of EMR on administration issues increased by 0.45 (0.37) standard deviations (Vishwanath et al., 2010). The attitudes of physicians were found to significantly predict their expectations of the impact of EMR workflow on administration issues, basic clinical processes, documentation, technical issues, communication and confidentiality. The documentation factor was the only one to be influenced by task-technology fit assessments. The interaction between attitudes and task-technology fit assessments was significant only in predicting efficiency in patient processing derived from EMR (Vishwanath et al., 2010).

Moreover, this study also found a significant difference between pre-implementation expectations and satisfaction levels three months following the implementation of EMRs. In all cases, satisfaction levels fell and did not meet expectations. Interestingly, a comparison of satisfaction levels three months and 20 months after implementation showed a slight increase in such levels, although none of the increases were statistically significant (Vishwanath et al., 2010).

A study in hospitals in the American Midwest was conducted in 2010. It comprised semi-qualitative research, with the results indicating that physicians in many ways believed that the use of EMR and CPOE improved the ease of personal performance (Holden, 2010). Aside from making personal performance easier, the physicians perceived EMR and CPOE to improve the quality of performance. In particular, they described more accurate and timely awareness of patient status, trends and other information, with many physicians appreciating that chest X-rays, CT scans and other results were available in real time (Holden, 2010). However, it also outlined how many perceived that EMR and CPOE worsened performance and made it more difficult and more complex (Holden, 2010). Information such as colleagues' notes, medications on the discharge list and data from other hospitals was described as difficult to access or find, while the additional demands and extra steps were perceived to increase the burden on physicians.

Table 1. Research Findings (Holden, 2010)

\begin{tabular}{ll}
\hline Variable & Results \\
\hline Behavioural beliefs & Quality of care was increased with EMR and CPOE use by allowing physicians to \\
Patient outcomes & up the delivery of care and by reducing the number of duplicate procedures that \\
may previously have been ordered. \\
Numerous patient safety benefits were believed to arise from EMR and CPOE use. \\
Of all the participants, 40\% (and 78\% in Hospital 2) believed that EMR and \\
CPOE use threatened patient safety due to, for example, physician over-reliance \\
on potentially erroneous information, nurses focusing more on complying with \\
EMR use protocol than on independently reviewing order accuracy, orders in the \\
system not being seen or neglected, and physicians speeding through the system or \\
ignoring CPOE alerts because they were accustomed to false alarms, meaning the \\
quality of care outcomes were perceived to be jeopardized by EMR and CPOE use.
\end{tabular}




\begin{tabular}{|c|c|}
\hline Variable & Results \\
\hline \multirow[t]{2}{*}{$\begin{array}{l}\text { Financial, organizational } \\
\text { and other outcomes }\end{array}$} & $\begin{array}{l}\text { Physicians believed that some cost savings resulted from eliminating dictation and } \\
\text { paper and from improved billing efficiency for billing departments and individual } \\
\text { physicians. }\end{array}$ \\
\hline & $\begin{array}{l}\text { However, physicians also believed that EMR and CPOE use led to an inefficient use } \\
\text { of resources due to some speciality-specific tools being described as lacking (e.g. } \\
\text { for drawing retinal images of ophthalmology patients), while template-based data } \\
\text { entry was perceived as not enabling physicians to record a rich, patient-specific } \\
\text { story in their notes. }\end{array}$ \\
\hline Affective outcomes & $\begin{array}{l}\text { Consistent with prior CPOE studies, most (91\%) were negative reactions such as } \\
\text { frustration, irritation and resentment. }\end{array}$ \\
\hline $\begin{array}{l}\text { External normative } \\
\text { beliefs }\end{array}$ & $\begin{array}{l}\text { Several entities, internal and external to the participants' hospitals or outpatient } \\
\text { clinics, were perceived to approve or encourage the use of EMR and CPOE by } \\
\text { physicians. Entities discouraging EMR and CPOE use were seldom mentioned. }\end{array}$ \\
\hline $\begin{array}{l}\text { Personal normative } \\
\text { beliefs }\end{array}$ & $\begin{array}{l}\text { Moral normative beliefs related to EMR and CPOE use were most commonly those } \\
\text { related to the confidentiality, privacy and security of patient records. Although } \\
\text { some perceived that using EMR and CPOE was a moral obligation, others had no } \\
\text { moral normative beliefs or belief that EMR and CPOE were morally neutral. }\end{array}$ \\
\hline $\begin{array}{l}\text { Control beliefs } \\
\text { Controllability }\end{array}$ & $\begin{array}{l}\text { For the most part, physicians believed that the use of EMR and CPOE was not } \\
\text { under their volitional control since it was mandated by the organization, because } \\
\text { some information was accessible only electronically, and generally because EMR } \\
\text { and CPOE were believed to have become 'as essential as carrying a pen and a } \\
\text { stethoscope', with physicians perceived to be 'reliant on the EMR now'. }\end{array}$ \\
\hline Self-efficacy & $\begin{array}{l}\text { Physicians reported numerous perceived barriers that might have limited their } \\
\text { ability to use EMR and CPOE, included perceived hardware and software barriers. }\end{array}$ \\
\hline Other beliefs & $\begin{array}{l}\text { 50\% of physicians noted the need for a fit between the system and other elements of } \\
\text { the work system, in addition to a perceived requirement to adapt in order to achieve } \\
\text { fit. Physicians provided detailed responses about their perceptions of the roll-out, } \\
\text { initial training and technical support, management support and commitment (most } \\
\text { believed that their hospital was very supportive and committed), user involvement } \\
\text { (some believed they were under-involved whereas others were content with a } \\
\text { low level of involvement), post-implementation modifications to the system, and } \\
\text { interactions with the vendor. }\end{array}$ \\
\hline
\end{tabular}

It stated that a large number of comments on the use of EMR and CPOE pertained to their effects on time-efficiency (Holden, 2010). A total of 70 per cent believed that EMR and CPOE saved time or sped up the care process, especially when retrieving information; however, almost every physician was also able to provide examples of perceived inefficiencies and time loss created by the use of EMR and CPOE, either through causing delays (e.g. when logging on or waiting for someone to enter data) or by slowing down work processes (Holden, 2010). This study also analysed other variables, with the results described in Table 1.

A study in the USA discussed the effect of EMR adoption in hospitals (Lee et al., 2013). Those hospitals adopting EMR experienced a fall in LOS of 0.11 days (95\% CI: -0.218 to -0.002$)$ and a 0.182 per cent lower 30 -day mortality, but a 0.19 (95\% CI: 0.0006 to 0.0033 ) per cent increase in 30-day rehospitalization in the two years after EMR adoption. The association of EMR adoption with outcomes also varied by type of admission (medical vs. surgical) (Lee et al., 2013).

Also, as a result of faster and more accurate communication and coordination among providers, EMR may contribute to reduced LOS; however, a shorter LOS may increase the 30-day rehospitalization rate because patients in a critical condition may return if they are discharged early, which is a problem that may be captured by EMR (Lee et al., 2013). It found that the effect of EMR on outcomes differed according to the type of diagnosis-related group (DRG) (Lee et al., 2013). 
EMR reduced the inpatient mortality rate in surgical DRGs, but it increased 30-day mortality. In medical DRGs, however, EMR increased LOS and 30-day rehospitalization but reduced 30-day mortality (Lee et al., 2013).

A study in Turkey focused on the views of nurses on EMR (Top \& Gider, 2011). By analyzing EMR from the perspectives of use, quality and user satisfaction, the study found an average score for nurses' satisfaction with EMRs of 3.28, an average score for using EMRs of 1.96, and an average score for the quality of EMRs of 3.16 (Top $\&$ Gider, 2011). It also determined the existence of significant relationships among the use, quality and user satisfaction of EMRs (Top \& Gider, 2011). The study revealed significant differences among the mean quality scores for EMR systems in a Ministry of Health hospital, university hospital and private hospital; interestingly, 59.0 per cent of all of the participants in the study felt that EMR systems were not well integrated into their workflow (Top \& Gider, 2011). It mentioned that a significant correlation was found among the use, quality and user satisfaction scores. Their correlation analysis revealed a significant correlation between the use and quality scores ( $\mathrm{r}$ $=0.512 ; \mathrm{p}<0.001)$, the use and user satisfaction scores $(\mathrm{r}=0.341 ; \mathrm{p}<0.001)$, and the quality and user satisfaction scores $(\mathrm{r}=0.536 ; \mathrm{p}<0.001)$ (Top \& Gider, 2011). The data showed that the highest correlation was between the quality and user satisfaction scores for EMR systems. All of the three subscales were positively correlated ( $\mathrm{p}$ $<0.001$ ) with each other (Top \& Gider, 2011).

A study examining the impact of EMR use on the patient-doctor relationship and communication was conducted in the USA in 2016 (Alkureishi et al., 2016). In this study, it stated that EMR use can improve patient understanding of conditions and treatment plans, in addition to increasing the sharing and confirmation of medical information (Alkureishi et al., 2016). It also mentioned that several studies have identified behaviors that appear to facilitate patient-centred communication (i.e. screen sharing, signposting, cessation of typing during sensitive discussions) and that future work should seek to incorporate these best practices into a curriculum for the purpose of teaching providers how to integrate patient-centred EMR use into their clinical workflow (Alkureishi et al., 2016). Medical education targeting the continuum of learners can address this gap in training and help foster humanistic patient-doctor EMR interactions in the digital age (Alkureishi et al., 2016).

\section{DISCUSSION \\ Advantages of Using EMRs}

Based on the 12 articles discussed above, we have found that the use of EMRs can provide a number of advantages. These are as follows: reduced LOS, decreased infection rate, decreased mortality rate, a reduction in mortality rate from AMI in years 2-3 of implementation, more complete filling in of medical records and clinical documentation, reduced hospitalizations and small decreases in the number of patient visits to emergency departments as a result of electronically generated reports of investigations containing care recommendations. EMRs were not found to reduce patient safety events; however, once such an event occurs, EMRs can serve to reduce deaths and readmissions. EMRs have also been found to reduce inpatient mortality rate in surgical DRGs. We can combine all of these benefits into one general variable termed 'outcomes'. EMR can increase cost per discharge while also leading to a reduction in excess spending due to patient safety events. EMRs can also lead to a decrease in RN and LVN cost per hour.

From the users' (physicians') perspective, they feel satisfied with the implementation of EMRs, which is aligned with the result of the others studies (Erawantini, Nugroho, Sanjaya, and Hariyanto, 2012). Physicians also believe that EMR has the potential to generate cost savings and improve billing efficiency. The reduced LOS associated with EMR suggests that EMR might enable faster physician ordering of tests, procedures and medications, speed up the process/scheduling of discharge and reduce delays in the service ordering process (Lee et al., 2013). The use of EMR has been shown to be related to quality and nurses' satisfaction, in line with the findings of a study (Top and Gider, 2011).

The use of EMR can also enhance the patient-doctor relationship due to the fact that doctors are able to educate their patients more 
easily, meaning that patients, in turn, are able to improve their understanding of their conditions and treatment plans. With EMR, doctors can share information with patients via a screen or other digital devices without needing to be concerned about patients not being able to interpret their handwriting. EMR can therefore also reduce the risk of patient safety incidents arising due to illegible handwriting.

\section{Disadvantages of Using EMRs}

Interestingly, from the 12 articles studied, we identified a number of similar research variables that produced different results, thereby revealing contradictory findings with regard to the effect of EMR implementation.

For example, it is mentioned above that EMR has the ability to reduce LOS. But some studies have shown that EMR actually leads to an increase in LOS, thus resulting in higher costs. EMR has also been found to have the effect of increasing nursing hours. While one study showed no significant effect of EMR on LOS in either ICU or for colorectal surgery patients, it has also been shown to increase the 30-day rehospitalization rate. In medical DRGs, EMR increases LOS. However, EMR has no significant effect on readmission. Another study found that EMR has no relationship with the mortality rate in hospitals, while EMR Stage 2 has little impact on patient outcomes.

From the cost and efficiency point of view, we conclude from the article that EMRs generate an increase in cost per patient stay accompanied by greater inefficiency in medical-surgical settings. The inefficiencies of EMR are associated with nursing documentation, electronic medication administration reports and CDS (Furukawa et al., 2010). EMR also has little relationship with nursing skill.

The rate of physician satisfaction in using EMR was low and did not meet expectations. Some physicians consider the use of EMR to increase their workload due to their own lack of ability with digital devices, which was especially true in the case of older physicians. Some physicians also consider EMR to make work processes slower as they have to wait for other people to input some of the data they need. Some physicians also mentioned that they were using EMR following an order from hospital management and not based on their own volition. Some physicians had concerns with regard to the security of patient data in EMR. They were concerned about the confidentiality and privacy of records. Some physicians also thought that EMR had the potential to make their role more difficult and complex. There thus appeared to be a variation in the disadvantages related to the stages of EMR.

\section{Challenge and Roles of Change Management Agents}

From the results and discussion above, we found that questions remain regarding the implementation of EMR. If hospital management is not able to properly undertake the implementation of an EMR system, there are likely to be obstacles to face. EMR implementation, as one part of a wider health technology system, requires a substantial amount of capital due to the fact that it necessitates an investment in IT systems; as such, an effective EMR system requires a steady system of IT (Veruswati \& Asyary, 2017).

The other important element in the success of EMR implementation is commitment (Veruswati \& Asyary, 2017). This must come not only from a hospital's management, but also from all components in the hospital, especially from users such as physicians, nurses, pharmacists and other health professionals. It is not always easy to build commitment, which is why change management agents have come to play a crucial role.

Change management agents should begin their work from the very outset of an EMR implementation; that is, as soon as the policy for EMR implementation has been released. To begin with, change management agents can conduct a socialization regarding the nature of EMR, the purpose of its implementation and the reasons for developing the policy. Change management agents should also seek to provide information on the likelihood of any difficulties and obstacles in the implementation. Change management agents should seek to become facilitators between the system users, hospital management and the vendors who will build the EMR system. As such, they act as a medium via which users can define 
their opinions, needs and expectations from the implementation of EMR. The most difficult part is then translating these user needs to the system vendors or Information and Technology Division, and vice versa (Veruswati \& Asyary, 2017). This part of the process will potentially require several rounds of communication or meetings to ensure the development of the same perception. By involving the users of a system, we would expect commitment to the implementation of EMR to be self-developing.

The other important part of an EMR implementation is the pre-implementation session. This would typically entail trial sessions to enable the users to adapt to the system. It is also during this pre-implementation stage that change management agents should seek to recognize users' difficulties. Change management agents must be capable of communicating and, if necessary, translating these problems to authorized personnel (i.e. to the vendors or Information and Technology Division) in order to provide solutions to the problems. Change management agents, along with authorized personnel, will then deliver the solution to users and should seek their opinions on it. Change management agents should also ensure they maintain a continuous and personal approach with regard to the users of the systems in order to secure their commitment and monitor whether there are any limitations.

Following the EMR go-live, the change management agents should monitor its implementation. This monitoring should include any obstacles and areas of compliance for the implementation of EMR. In conclusion, the change management agents should undertake a comprehensive evaluation of the implementation of EMR. It is preferable for such an evaluation to be carried out on a regular basis (e.g. monthly or every three months) in order to enable the prompt identification of any obstacles, ensure that any risks can be mitigated and the objectives of the implementation can be achieved.

The limitation of our study is based on the fact that we were unable to source any articles pertaining to a cost-benefit analysis or costeffectiveness analysis on the implementation of
EMR. Therefore, we were unable to access any further information in terms of its benefit from a cost-efficiency perspective.

It is best if hospitals seek to undertake a comprehensive analysis and evaluation both prior to and after the implementation of EMR. It is also important to involve the ultimate users of the system, notably physicians, during the design and build phase of the EMR. In hospitals that already have a universal health coverage system, the implementation of EMR may be considered due to its advantages in terms of reducing paperbased medical records and increasing patient safety by eliminating illegible handwriting. For hospitals that have already implemented a system of EMR, it is better to enhance their EMR to become Electronic Health Records (EHR) and patients' personal health records.

We would suggest that the next researcher seeking to conduct a study into the benefits of implementing a system of EMR, especially when looking at the efficiency aspects, either finds or conducts some research that also incorporates a discussion on cost-benefit analysis or the costeffectiveness of using EMRs.

\section{CONCLUSION}

Despite the fact that the implementation of EMR has the potential to yield both advantages and disadvantages, it remains a contentious and interesting topic for discussion. Some hospitals consider the implementation of an EMR system to be a large investment with the potential to increase the investment cost. Another challenge regarding the implementation of EMR involves the building of commitment, not only from hospital management but from all stakeholders in the hospital. Hospital management should seek to undertake more analysis and give greater consideration not only to the efficiency aspect but also to the quality of hospital care, prior to deciding on whether or not to use EMR.

\section{ACKNOWLEDGEMENTS}

We would like to thank our family and colleagues at the Faculty of Public Health Universitas Indonesia and Britannia Proofreading Service team for their support. 


\section{REFERENCES}

Andriani, R., Kusnanto, H., \& Istiono, W. (2017). Analisis kesuksesan implementasi rekam medis elektronik di RS Universitas Gadjah Mada. Jurnal Sistem Informasi (Journal of Information Systems), 2/13, 90-96

Alkureishi, M. A., Lee, W. W., Lyons, M., Press, V. G., Imam, S., Nkansah-Amankra, A., \& Arora, V. M. (2016). Impact of electronic medical record use on the patient-doctor relationship and communication: A systematic review. $J$ Gen Intern Med, 31(5), 548-560.

Asyary A, Kusnanto H, Fuad A. Sistem Peresapan Elektronik pada Keselamatan Pengobatan Pasien. Kesmas: National Public Health Journal. 2013;8(3):119-124.

Encinosa, W., \& Bae, J. (2012). How can we bend the cost curve? Health information technology and its effects on hospital costs, outcomes, and patient safety. Inquiry, 48(4), 288-303. https:// www.jstor.org/stable/23110290

Erawantini,F.,Nugroho,E., Sanjaya, G.Y.,\&Hariyanto, S. (2012). Rekam medis elektronik: Telaah manfaat dalam konteks pelayanan kesehatan dasar. http://www.download.portalgaruda.org/ article.php?article $=113517 \&$ vas $=5182$

Feldstein, P. J. (1983). Health care economics, 2nd edition. John Wiley \& Sons.

Furukawa, M. F., Raghu, T. S., \& Shao, B. B. (2010). Electronic medical records and cost efficiency in hospital medical surgical units. Inquiry, 47(2), 110-123. www.inquiryjournal.org.

Furukawa, M. F., Raghu, T. S., \& Shao, B. B. (2010). Electronic medical records, nurse staffing, and nurse-sensitive outcomes: Evidence from California hospitals, 1998-2007. Health Research and Educational Trust. HSR: Health Services Research, 45(4), 941-962.

Henderson, J. (2002). Health economics and policy. Baylor University. South-Western Thomson Learning. United States of America.

Holden, R. J (2010). Physicians' beliefs about using EMR and CPOE: In pursuit of a contextualized understanding of health IT use behavior. International Journal of Medical Informatics, 79(2), 71-80.
Keasberry, J., Scott, I. A., Sullivan, C., Staib, A., \& Ashby, R. (2017). Going digital: A narrative overview of the clinical and organizational impacts of eHealth technologies in hospital practice. Australian Health Review, 41(6), 646664.

Lee, J., Kuo, Y-F., \& Goodwin, J. S. (2013). The effect of electronic medical record adoption on outcomes in US hospitals. BMC Health Services Research, 13(1), 39, doi: 10.1186/1472-6963-1339.

Santerre, R., \& Neun, S. (2010). Health economics. Theory, insights, and industry studies. Cengage Learning.

Top, M., \& Gider, O. (2011). Nurses' views on electronic medical records (EMR) in Turkey: An analysis according to use, quality and user satisfaction. J Med Syst, 36(3), 1979-1988.

van Poelgeest, R., van Groningen, J. T, Daniels, J. H., Roes, K. C., Wiggers, T., Wouters. M. W., \& Schrijvers. J. (2017). Level of digitization in Dutch hospitals and the length of stay of patients with colorectal cancer. $J$ Med Syst, 41, 84, doi: 10.1007/s10916-017-0734-3.

Vishwanath, A., Singh, S. R., \& Winkelstein, P. (2010). The impact of electronic medical record systems on outpatient workflows: A longitudinal evaluation of its workflow effects. International Journal of Medical Informatics, 79(11), 778-791.

Veruswati M., \& Asyary A. Implementation of Information System Towards Health System Strengthening in Indonesia: A Policy Brief. Public Health of Indonesia 2017;3(3):73-76

World Health Organization (2018). WHO Terminology Information System (Online Glossary). http:// www.who.int/health-systems-performance/docs/ glossary.htm

Xue, Y., Liang, H., Wu, X., Gong, H., Li, B., \& Zhang, Y. (2012). Effects of electronic medical records in a Chinese hospital: A time series study. International Journal of Medical Informatics, 81(10), 683-689. 


\begin{tabular}{|c|c|c|c|c|c|}
\hline 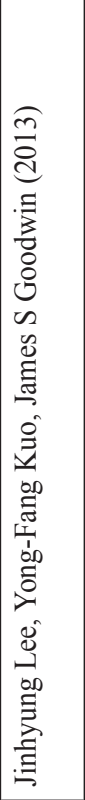 & 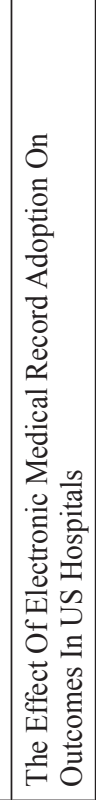 & 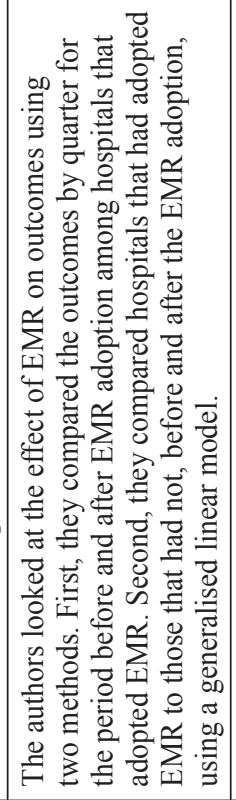 & 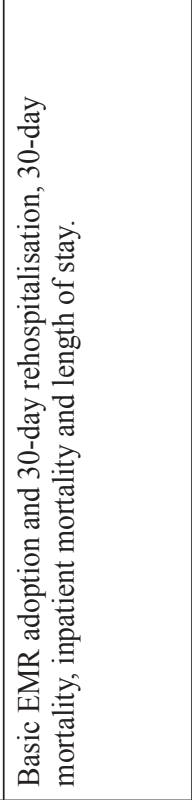 & 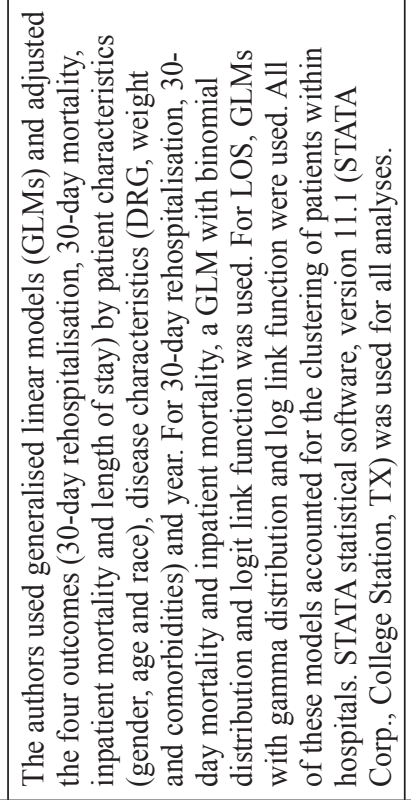 & 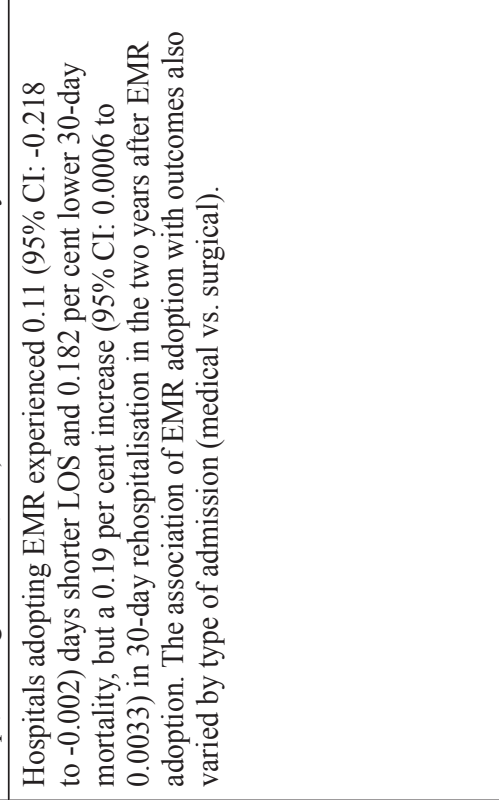 \\
\hline 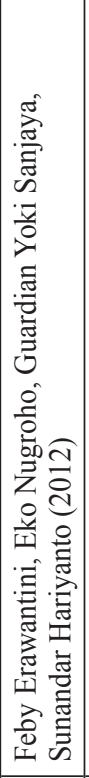 & 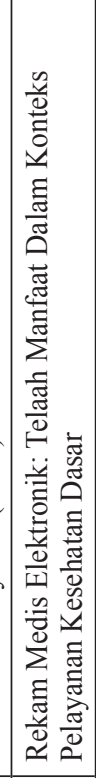 & 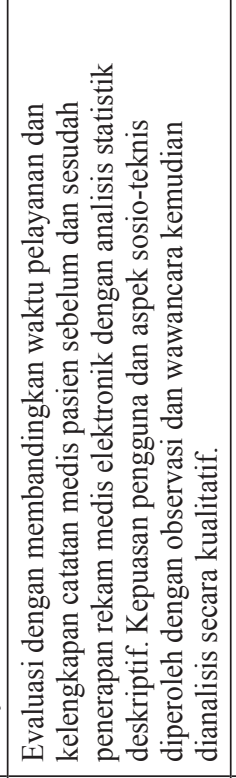 & 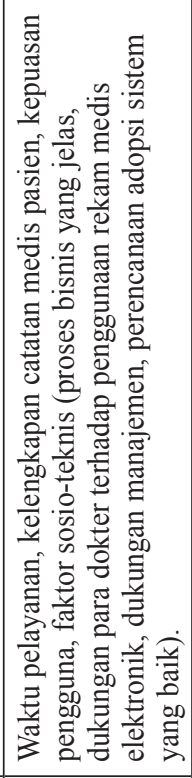 & 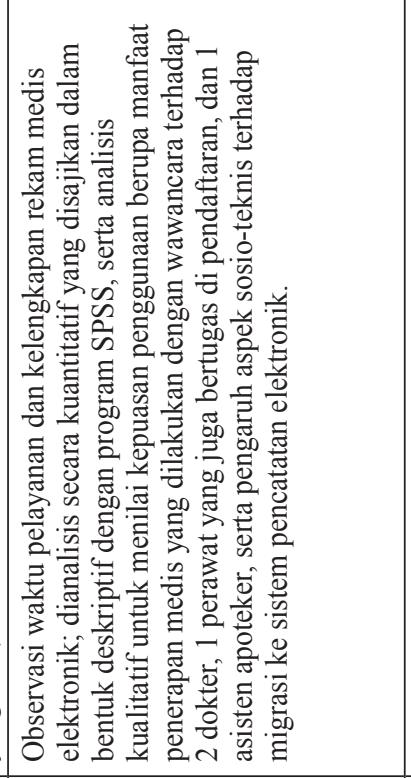 & 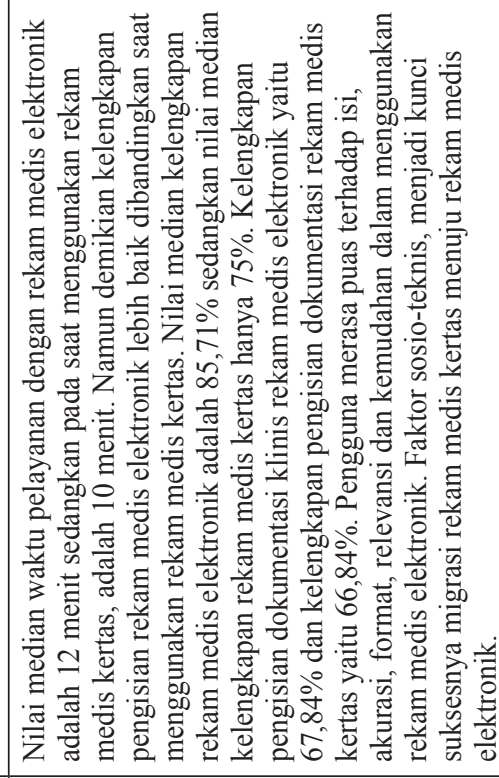 \\
\hline 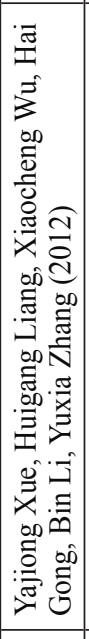 & 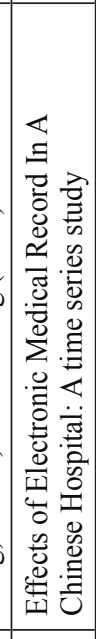 & 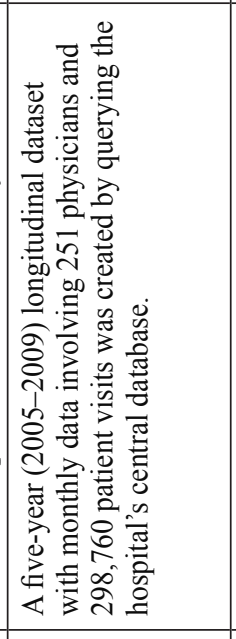 & 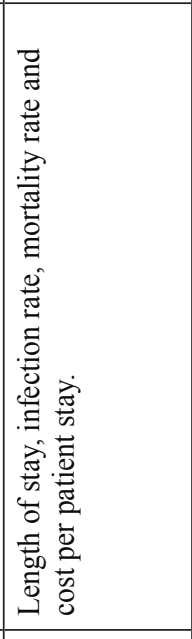 & 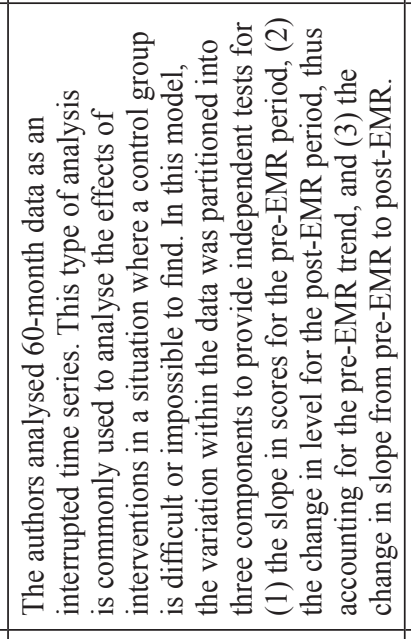 & 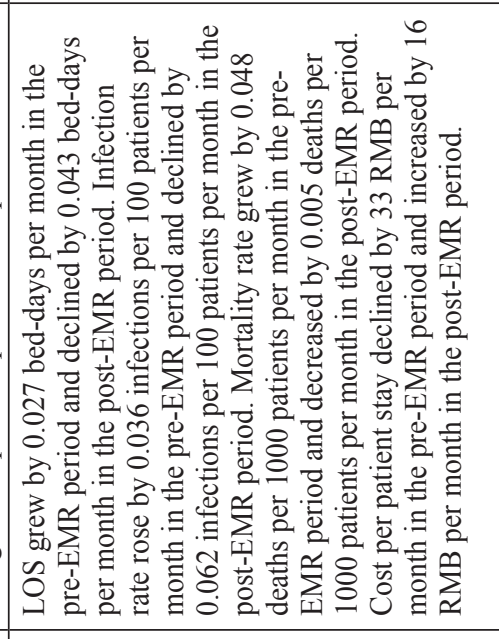 \\
\hline 鞄 & & 赔 & 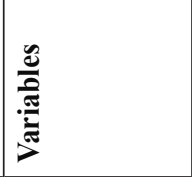 & $\frac{\sqrt{2}}{4}$ & $\begin{array}{l}\text { 訔 } \\
\cong\end{array}$ \\
\hline
\end{tabular}




\begin{tabular}{|c|c|c|c|c|c|}
\hline 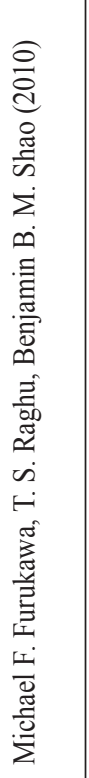 & 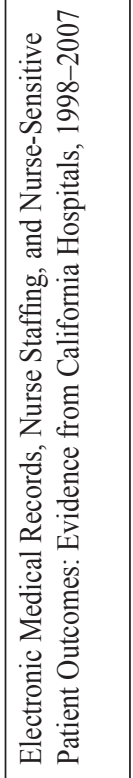 & 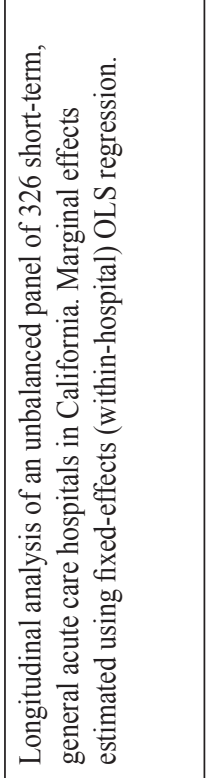 & 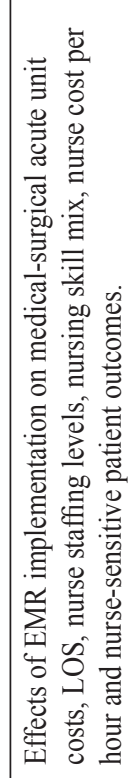 & 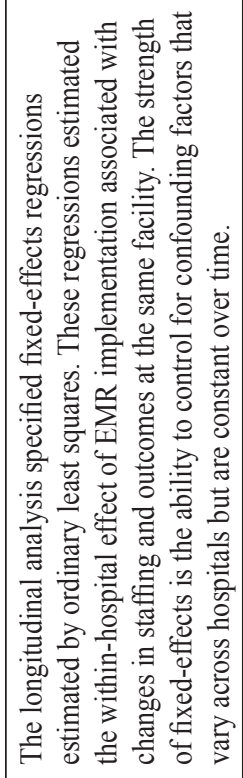 & 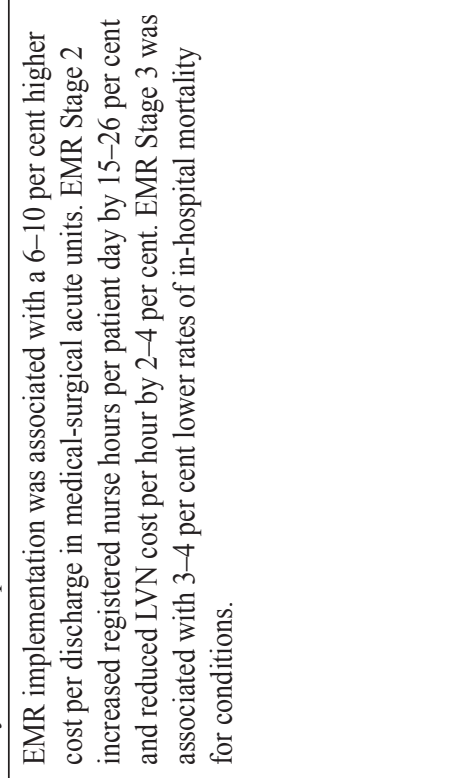 \\
\hline 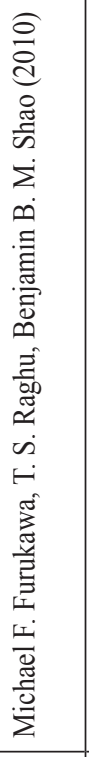 & 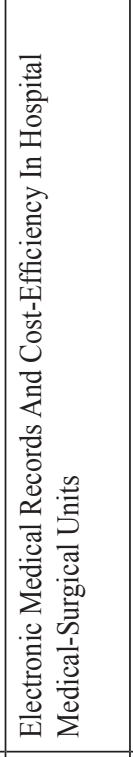 & 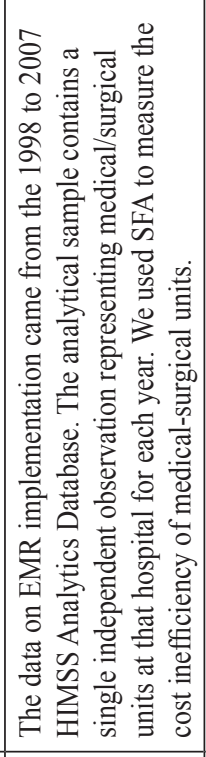 & 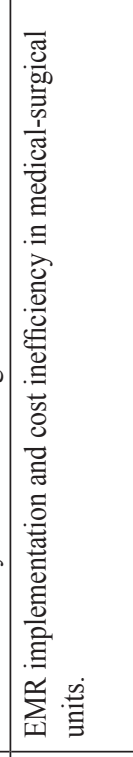 & 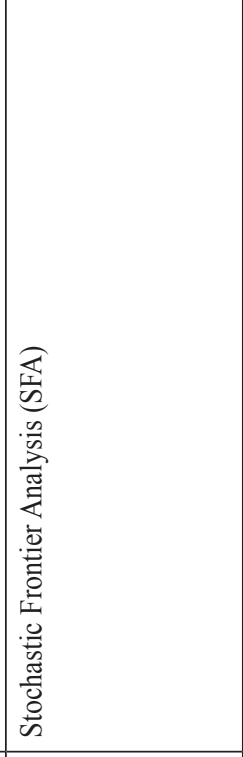 & 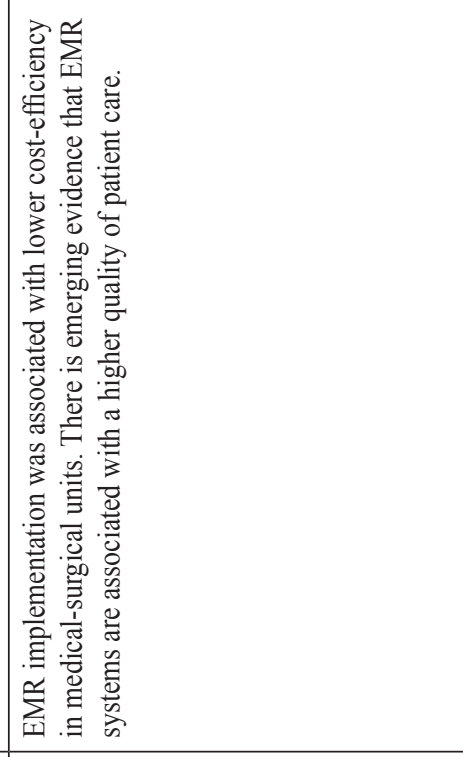 \\
\hline 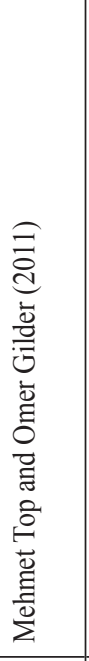 & 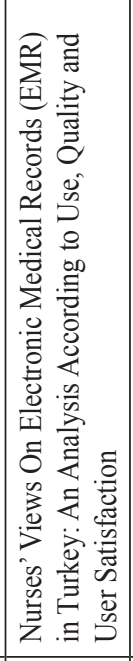 & 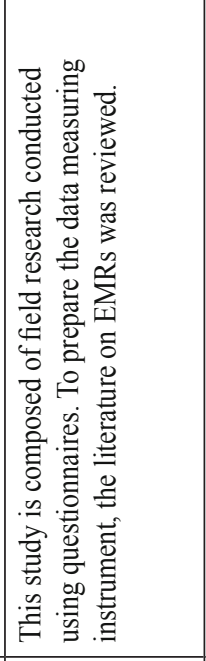 & 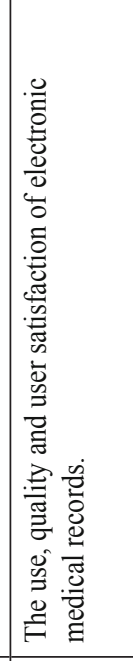 & 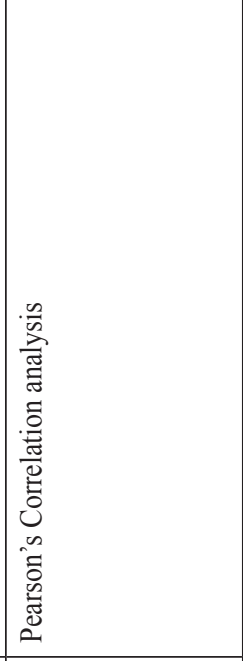 & 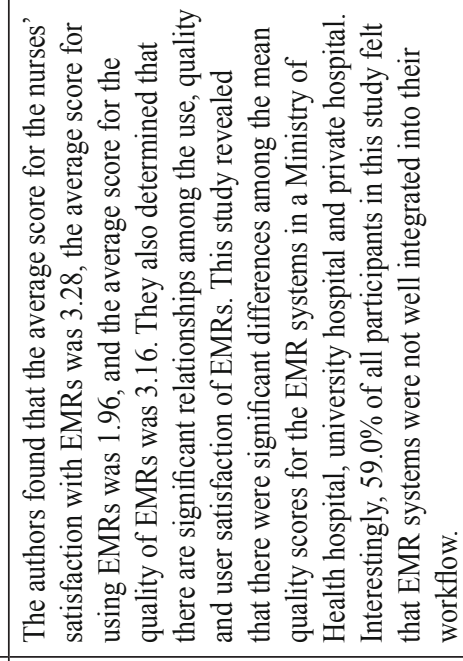 \\
\hline 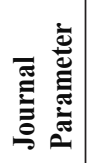 & $\stackrel{\Xi}{\Xi}$ & 餀 & 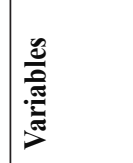 & $\frac{2}{\pi}$ & $\approx$ \\
\hline
\end{tabular}




\begin{tabular}{|c|c|c|c|c|c|}
\hline 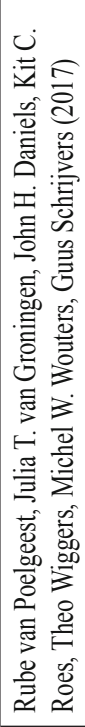 & 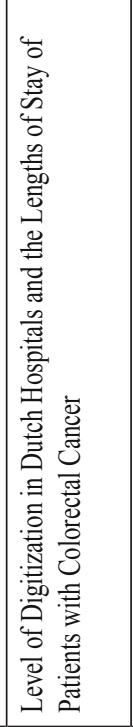 & 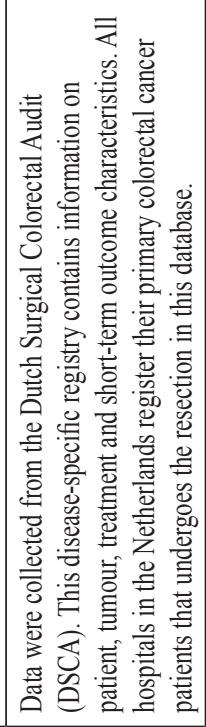 & 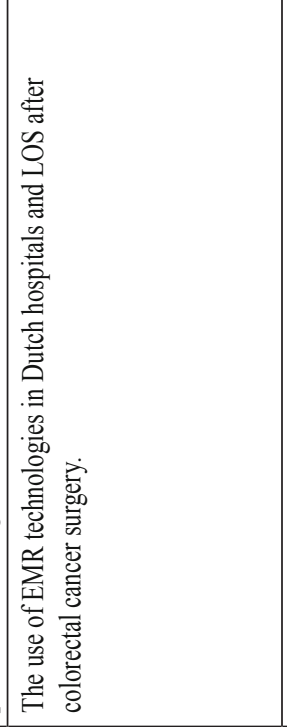 & 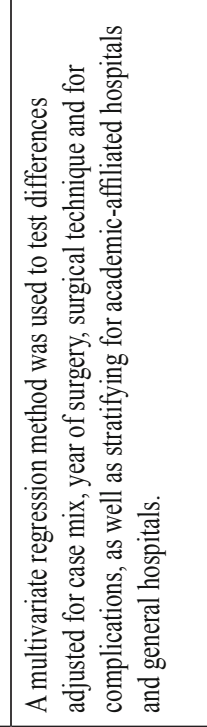 & 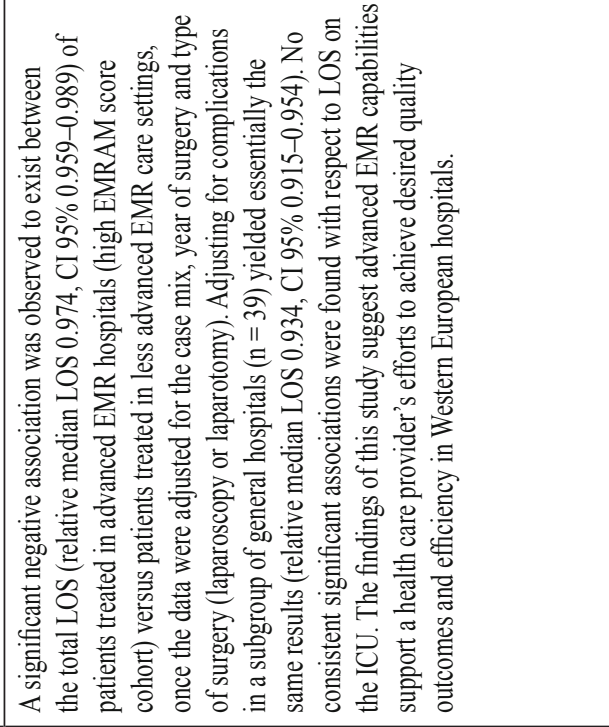 \\
\hline 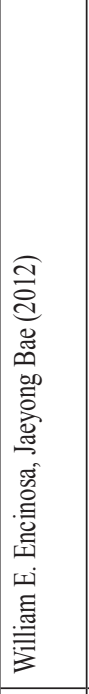 & 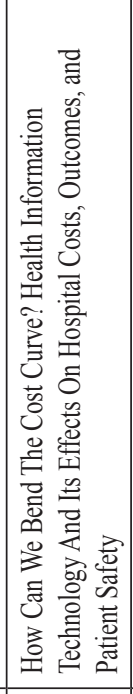 & 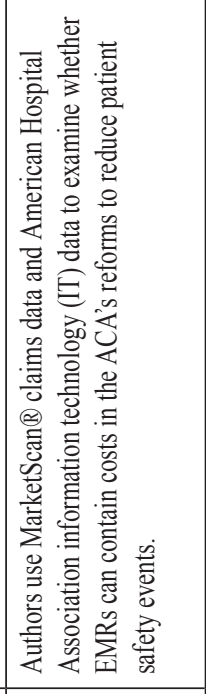 & 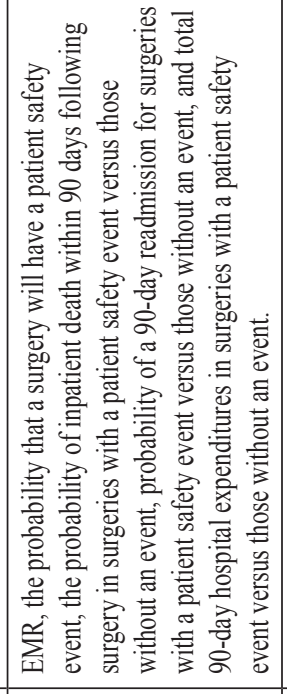 & 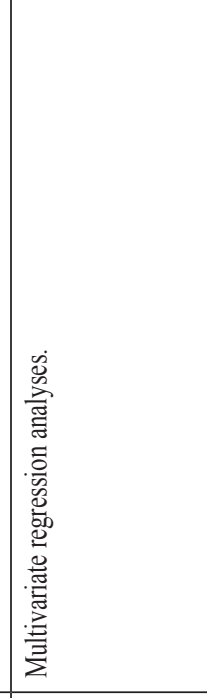 & 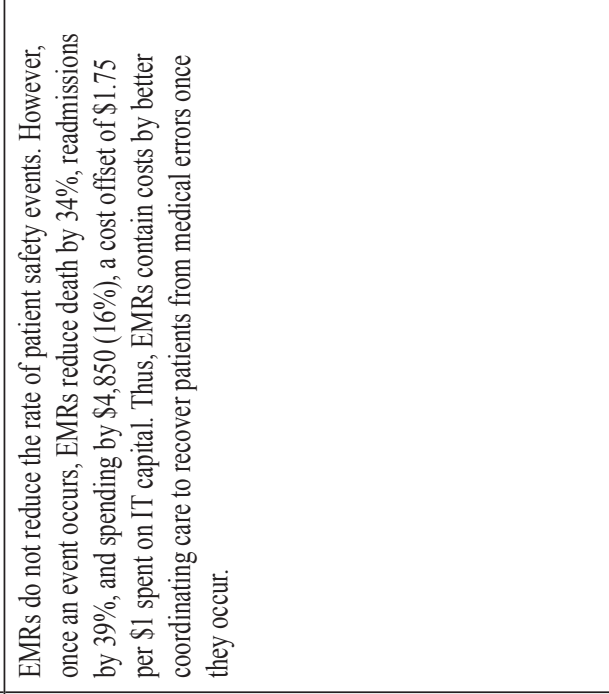 \\
\hline 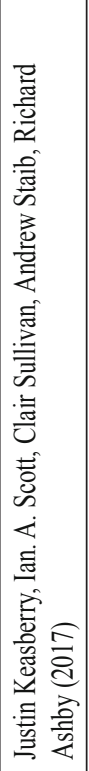 & 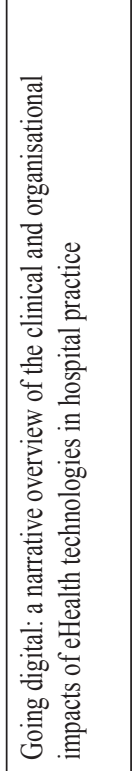 & 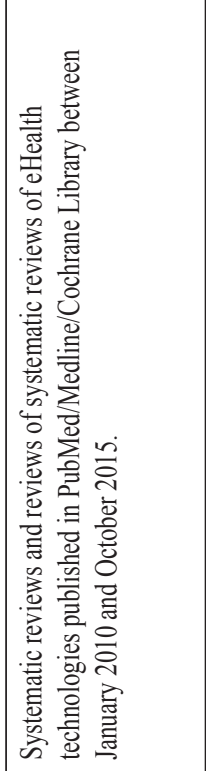 & 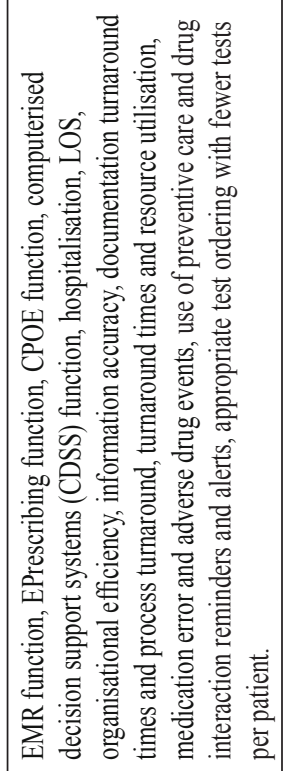 & 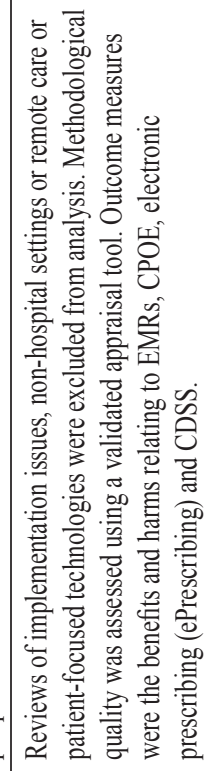 & 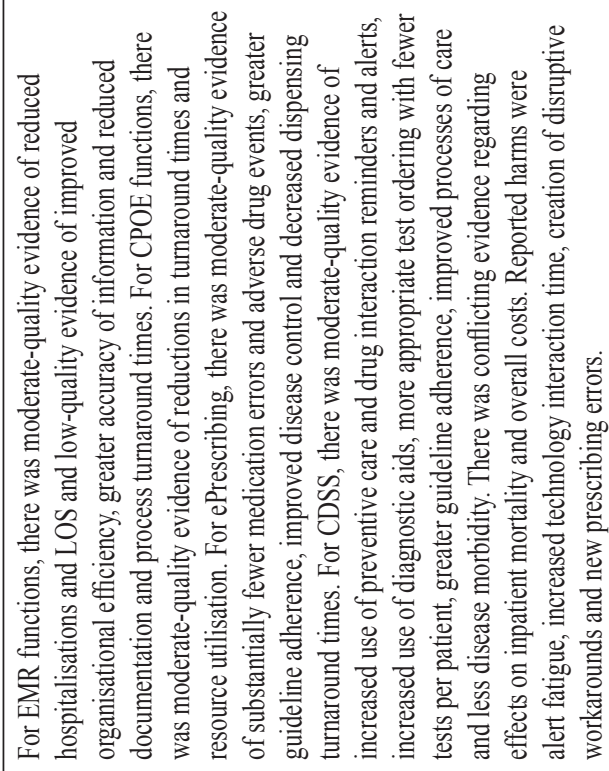 \\
\hline 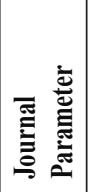 & $\Xi$ & 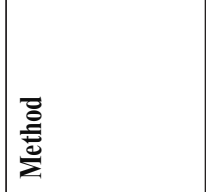 & 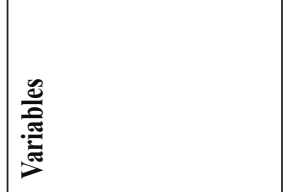 & $\frac{2}{4}$ & $\cong$ \\
\hline
\end{tabular}




\begin{tabular}{|c|c|c|c|c|c|}
\hline 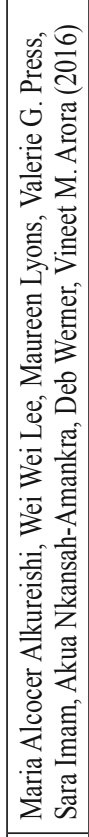 & 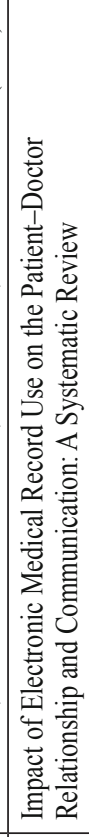 & 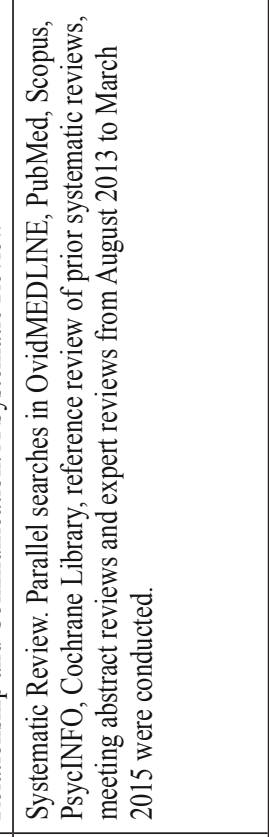 & 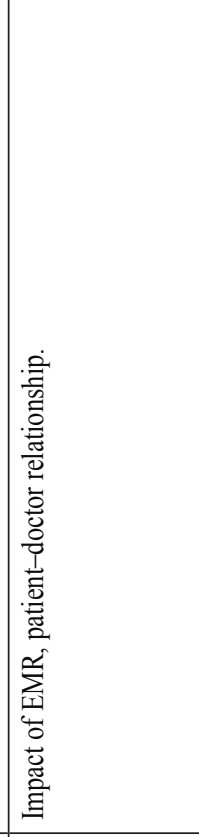 & 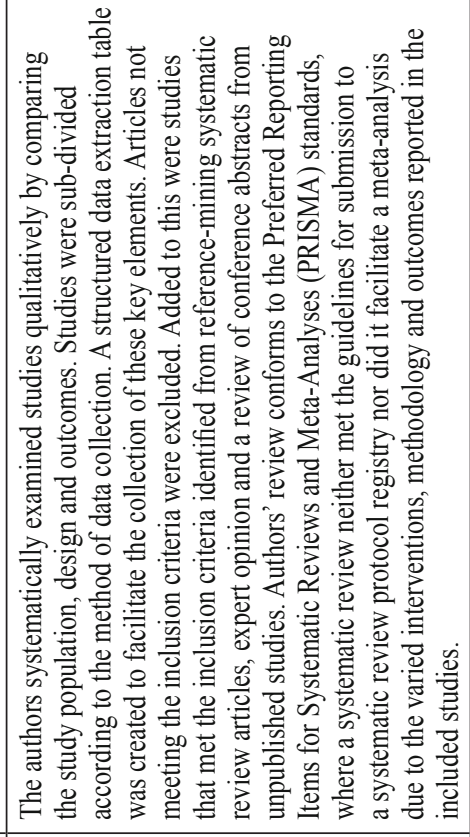 & 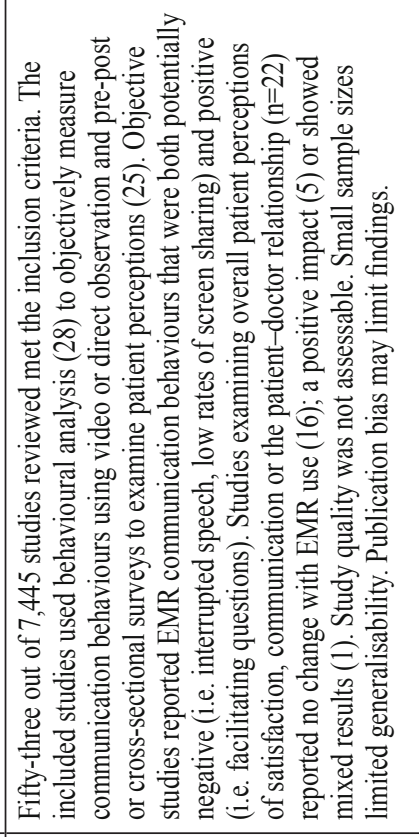 \\
\hline 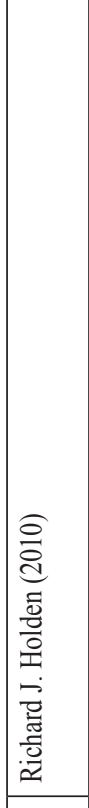 & 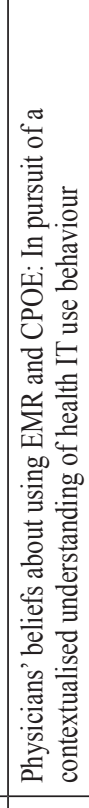 & 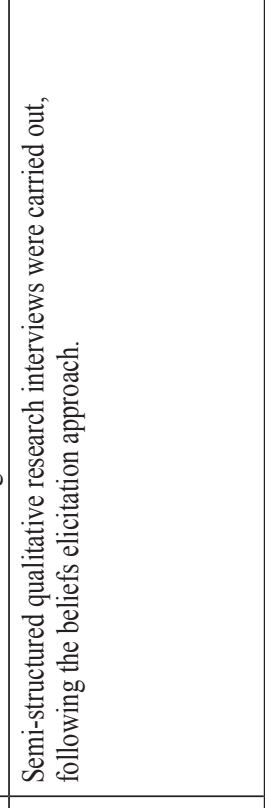 & 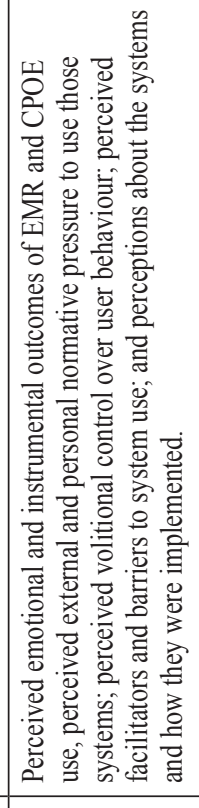 & 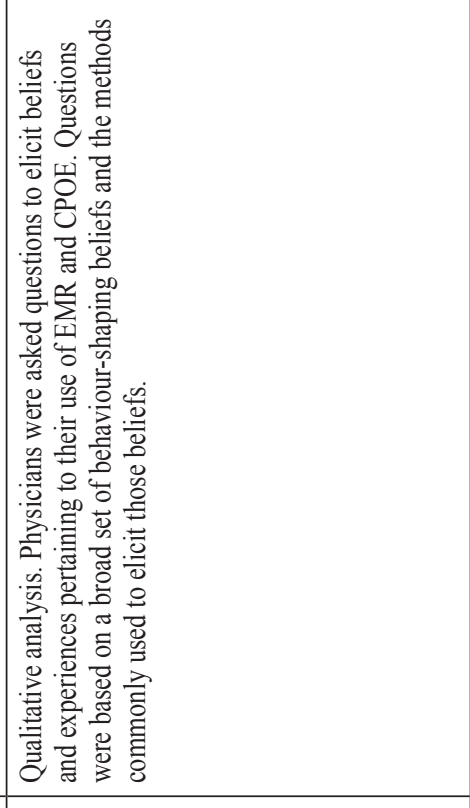 & 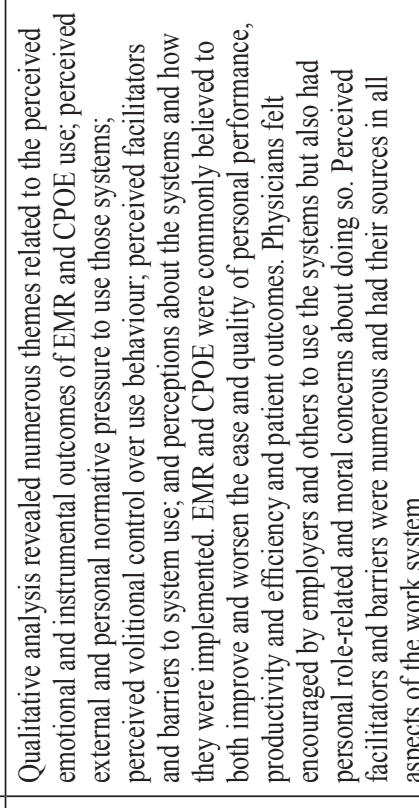 \\
\hline 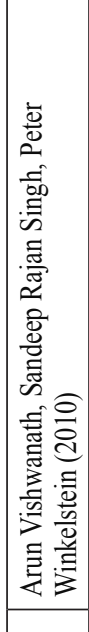 & 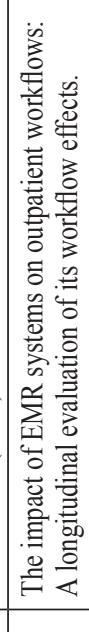 & 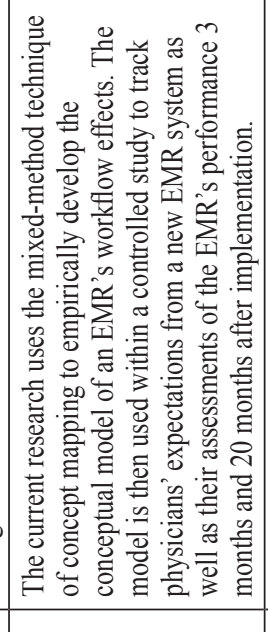 & 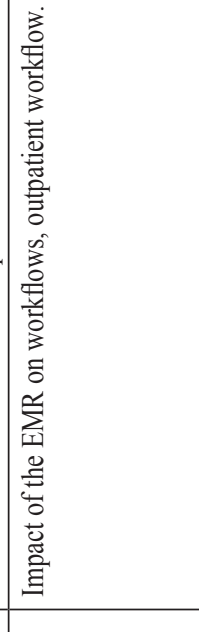 & 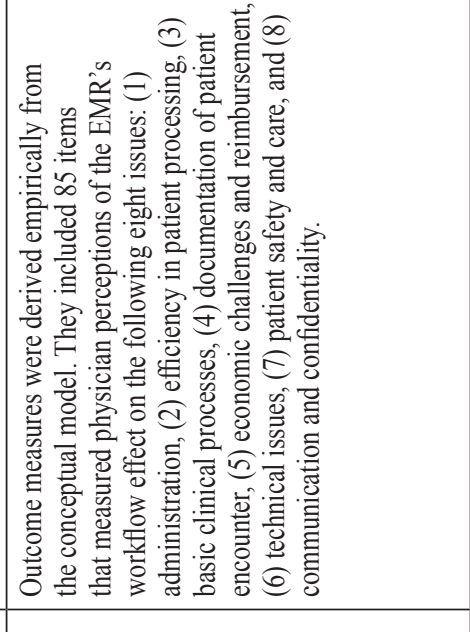 & 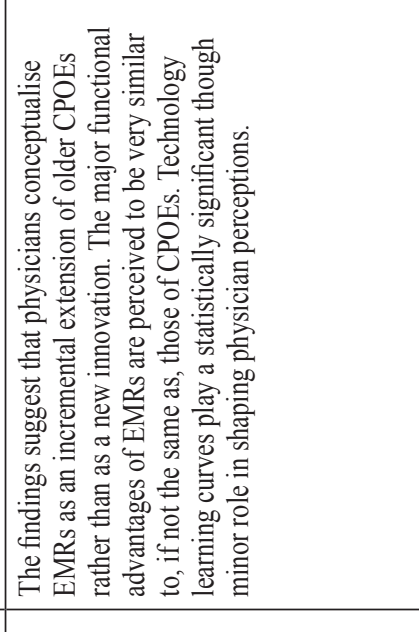 \\
\hline 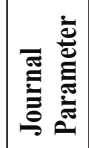 & & 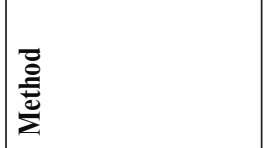 & 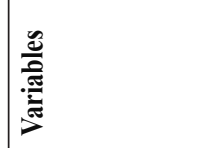 & 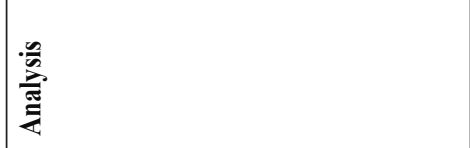 & 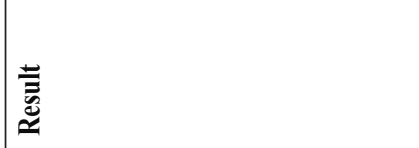 \\
\hline
\end{tabular}

